Mohammed Akter Hossain

Hakan Acet"

Zobayer Ahmed"*

Alauddin Majumder

Recibido: 13 de febrero de 2021

Evaluación: 15 de julio de 2021

Aprobado: 31 de julio de 2021

Artículo de investigación

(c) 2021 Universidad Católica de Colombia.

Facultad de Ciencias

Económicas y Administrativas.

Todos los derechos reservados

* Graduate, Department of Economics \& Banking, International Islamic University Chittagong, Bangladesh, Email: hossainiiuc8319@gmail.com

(D) https://orcid.org/0000-0001-7637-0110

** Associate Professor, Department of Economics, Selçuk Üniversitesi, Konya, Turkey.Email: hakanacet@selcuk.edu.tr

(D) https://orcid.org/0000-0003-4314-8657

*** Assistant Professor, Department of Economics \& Banking, International Islamic University Chittagong, Bangladesh. PhD Student, Department of Economics,

Selcuk University, Konya, Turkey. Email: ecozobayer@gmail.com

(D) https://orcid.org/0000-0002-3168-6055

**** Professor, Department of Economics, University of Chittagong, Bangladesh, Email: ecoalauddin@cu.ac.bd

(D https://orcid.org/0000-0002-3805-7956

\section{Revisiting inflation and growth nexus in Bangladesh: an asymmetric cointegration based on non-linear ARDL approach}

\begin{abstract}
Sustainable high economic growth is the major objective of a country. In contrast, inflation is a critical issue that alters economic development. For this, the growth-inflation nexus is one of the most controversial topics in this present world. This study re-investigates the link between inflation and the economic development of Bangladesh by applying a nonlinear autoregressive distributed lagged (NARDL) method. We utilize yearly time series data set on the growth rate of per capita GDP and the inflation rate for the time range from 1986 to 2017. Based on the NARDL approach, the asymmetric cointegration result confirms, between the GDP growth and inflation rates (CPI), a long-run integration exists. Between growth rate and inflation rate, the study finds a positive and robust nexus both in the long-run and in the short-run with statistically significant results. This study further explores an asymmetric relationship between the rate of inflation and the rate of economic growth. The nonlinear ARDL approach shows that the GDP growth rate responds more with an upward change in inflation than a downward change. Furthermore, the positive change in inflations has a significant and positive influence on the growth rate in the short run. Still, the effect of an adverse change in inflations has statistically insignificant. Both the policymakers of Bangladesh (Bangladesh Bank) and development partners working in the country can be benefited from these results in the context of policy implementation. To boost the economic growth in the context of Bangladesh, this study recommends that a moderate inflation rate can be treated as a significant determination.
\end{abstract}

Keywords: asymmetric co-integration, Bangladesh, economic growth, inflation, Non-linear Autoregressive Distributed Lagged (NARDL) Model.

JEL Classification: C32, E31, O11, O40, R48, Y1 


\section{Revisando el nexo entre la inflación y el crecimiento en Bangladesh: una cointegración asimétrica basada en un enfoque ARDL no lineal}

\section{Resumen}

El alto crecimiento económico sostenible es el principal objetivo de un país. Por el contrario, la inflación es un tema crítico que altera el desarrollo económico. Por ello, la relación crecimiento-inflación es uno de los temas más controvertidos en el mundo actual. Este estudio investiga el vínculo entre la inflación y el desarrollo económico de Bangladesh mediante la aplicación de un método de distribución rezagada no lineal autorregresivo (NARDL). Utilizamos series de datos anuales establecidas sobre la tasa de crecimiento del PIB per cápita y la tasa de inflación para el rango de tiempo de 1986 a 2017. Con base en el enfoque NARDL, el resultado de cointegración asimétrica confirma, entre el crecimiento del PIB y las tasas de inflación (IPC), existe una integración a largo plazo. Entre la tasa de crecimiento y la tasa de inflación, el estudio encuentra un nexo positivo y robusto tanto a largo como a corto plazo con resultados estadísticamente significativos. Este estudio explora más a fondo una relación asimétrica entre la tasa de inflación y la tasa de crecimiento económico. El enfoque ARDL no lineal muestra que la tasa de crecimiento del PIB responde más con un cambio ascendente en la inflación que con un cambio descendente. Además, la variación positiva de las inflaciones tiene una influencia significativa y positiva en la tasa de crecimiento a corto plazo. Aún así, el efecto de un cambio adverso en las inflaciones ha sido estadísticamente insignificante. Tanto los formuladores de políticas de Bangladesh (Banco de Bangladesh) como los socios de desarrollo que trabajan en el país pueden beneficiarse de estos resultados en el contexto de la implementación de políticas. Para impulsar el crecimiento económico en el contexto de Bangladesh, este estudio recomienda que una tasa de inflación moderada puede tratarse como una determinación significativa.

Palabras clave: Cointegración asimétrica, Bangladesh, Crecimiento económico, Inflación, Modelo de distribución rezagada no lineal autorregresivo (NARDL). 
Revisiting inflation and growth nexus in Bangladesh: an asymmetric cointegration based on non-linear ARDL approach

\section{INTRODUCTION}

Inflation is described as a permanent growth in the general level of prices in the economy of a country, which indicates decreasing purchasing power by increasing living costs. It is crucial to note that the changing general price level must be permanent to be treated as inflation. Inflation is treated as one of the most vital economic indicators that have drawn broad attention for both developed and developing countries. In macroeconomics theory, traditional views claim that low inflation is necessary for an economy to boost economic development. As a policy, every country should achieve sustainable economic growth with a stable price level. Therefore, a monetary policy with a relatively stable price and fiscal policy with productivity should be coordinated and implemented effectively. It can be challenging for a policymaker to maintain price stability and sustainable growth simultaneously.

Recently, inflation has drawn the broad interest of policymakers, macroeconomists, academicians, and the central bank authority. In every country, macroeconomic policy depends on the dynamics between economic growth and inflation. Notably, the question generates a theoretically and empirically debate on whether inflation is favourable for economic growth or unfavourable to growth. This debate generally arises from the counter confrontational views between the monetarists and the structuralists. Mundell (1965) and Tobin (1965) forecast a positive nexus between capital accumulation and inflation, indicating a positive association concerning economic growth and inflation. The dispute is that capital and money substitute for each other. Due to a rise in inflation, capital accumulation increases by moving the portfolio from money to capital. Thus, it motivates for a higher rate of economic growth (Gregorio, 1999). Conversely, Fischer and Modigliani (1978) recommended an antagonistic and nonlinear connection between economic growth and inflation by employing the new growth theory (Shamim Ahmed, 2005). They argue that economic development is hampered by inflation broadly by reducing investment efficiency rather than the investment level.

Up to the present time, though the inflation-growth affiliation is still debatable and inconclusive, a considerable number of empirical works explore the relationship between these two critical macroeconomic variables and found controversial results; positive, negative, or neutral. Further, they investigate whether the relation between two variables is linear or not. Due to the inflationary spiral and national expectations for inflation, gradually rising general price level can turn into a high price level and create instability in macroeconomic phenomena, which is harmful to 
sustainable economic development (Econometrics, 2007; Feldstein, 1980; Khan \& Ssnhadji, 2001). At the same time, disinflation or zero levels of inflation hurts economic growth because of negative motivations for production. Besides, a universal concept gradually grows that relatively lower and steady inflation positively motivate economic growth, and sustainable economic growth can be achieved through moderate inflation (Mubarik \& Riazuddin, 2005). The question, furthermore, raises how the direction between inflation and economic growth is. The solution to this issue relies on the type and composition of the economy that differs across the countries.

The prime objective of this research is to empirically determine the current economic growth - inflation nexus for Bangladesh. The necessity of this investigation is that international financial loaning agencies (ADB, the World Bank, and IMF) create pressure on the monetary authority of Bangladesh to control the rates of inflation so that Bangladesh can stimulate economic development. Besides, Our study has been inspired by the empirical work of Mallik \& Chowdhury (2001) and (Ahmed \& Mortaza, (2010). Engle-Granger two-step co-integration formula was applied in those studies to examine the inflation-growth relationship for the economy of Sri Lanka, Pakistan, India, and Bangladesh. We are also invigorated by the works of Khan and Sanhadji (2001) for 140 developing countries, Mubarik \& Riazuddin, (2005) for Pakistan economy and Sweidan, (2004) for Jordan. Finally, we have encouraged applying the Non-linear Autoregressive Distributed Lagged (NARDL) model to explore the long-run and the short-run asymmetric relation between concerned variables. This empirical study has employed using annual time series data set on the rate of the growth of per capita GDP and Consumer Price Index (CPI) for inflation over the time range of 1986 to 2017. The findings can offer a direction not only to the policymakers but also to the development partners. It might, however, be the more appropriate to explore the nexus concerning inflation and economic development with a large sample size.

A set of empirical articles have scrutinized the effect of inflation on the economic growth of many emerging economies by utilizing panel data for group countries and time-series data over the years. There is a long-run significant negative relationship between inflation and growth in Sri Lanka (Madurapperuma, 2016). Nevertheless, in an earlier study comprised Sri Lanka, Pakistan, India, and Bangladesh; for all four countries, Madurapperuma (2016), (Mallik and Chowdhury, 2001) discovered a positive relationship between inflation and growth.

However, a country-specific study is needed, especially for Bangladesh. There are rare research that attempted to explore the relationship between the inflation 
Revisiting inflation and growth nexus in Bangladesh: an asymmetric cointegration based on non-linear ARDL approach

rate and economic growth in Bangladesh with inconclusive results. Some studies find a long-run relationship between them. The short-run relation is absent in those studies. Besides, over the last few decades, the monetary authority of Bangladesh has been facing pressures from international financial loan providing institutions such as ADB, the World Bank, and IMF to reduce its inflation rates to improve economic growth (Mallik \& Chowdhury, 2001). Further, a universal concept gradually arises that sustainable economic growth can be attained through stable prices and moderate inflation (Mubarik \& Riazuddin, 2005).

Now consider the uniqueness of the current study. Most of the relations between the macroeconomic variables are not symmetric or linear. Shin et al. (2014) argued, "nonlinearity is widespread within the social sciences, and the asymmetry is fundamental to the human condition." Majority researches on the economic growth-inflation nexus have revealed symmetric or linear coefficients contradictory to the real world. To fulfil the underlined gap, this study attempts to the economic growth-inflation relation by exploring a realistic parameter. This study investigates both the short-run and long-run asymmetric relationship between the inflation rate and economic growth for Bangladesh. The Non-linear Autoregressive Distributed Lagged (NARDL) model, a newly developed by Shin et al. (2014), has been employed to examine the relationship between concerned variables. Moreover, our study also contains updated data from 1986 to 2017 and more observations than any other study.

The major objective of this study is to re-scrutinize the actual relation between economic growth and inflation for Bangladesh. s. There are two specific objectives of this study;

Objective-01: To examine the nature of the long-run and the short-run relation between economic growth and inflation.

Objective-02: To re-investigate the direction of the relationship, whether is it symmetric or asymmetric between economic growth and inflation for Bangladesh?

\section{AN OVERVIEW OF INFLATION AND ECONOMIC GROWTH IN BANGLADESH}

Bangladesh is the newest developing economy in the South Asia zone in the world. In the early 1990s, Bangladesh economy has re-established healthy economic growth and macroeconomic stability. After the early birth of independence, the economy of 
Bangladesh has experienced a tremendous macroeconomic crisis (Shamim Ahmed, 2005). When compared to the 1980s, the economy grew at a faster rate in the early 1990s. Following that era, however, the economy was hit by the most severe strains, including dwindling foreign exchange reserves, poor government budgetary balances, and rising inflationary pressures (Mahmud, 1997).

Figure 1 illustrates that GDP growth gradually increased while inflation was decreasing, but the latter was growing. The GDP growth rate increased moderately until the 2000s, when the inflation rate declined progressively, and it was found below 5-percent. In the following period, inflation rates had dramatically increased, and a stable inflation rate was observed from 2010 to 2015. However, rising GDP growth rates were found in the economy of Bangladesh over the study period. In the first half of the $2000 \mathrm{~s}$, the average inflation rate was experienced at 4.57 percent, while the average GDP growth rate was found at 2.53 percent. Although the average inflation rate rapidly increased and was found at 7.37 percent in the period from 2005 to 2010, the growth rate of GDP continued to grow. From 2010 to 2015, both inflation and growth rate were stable at approximately 7.35 percent and 4.97 percent, respectively. In the last two years, the inflation rate decreased while GDP growth was still moderately increasing. The average inflation rate is seen approximately 6 percent over study time.

Figure 1. GDP Growth and Inflation Rates as Five Year Average (1986-2017)

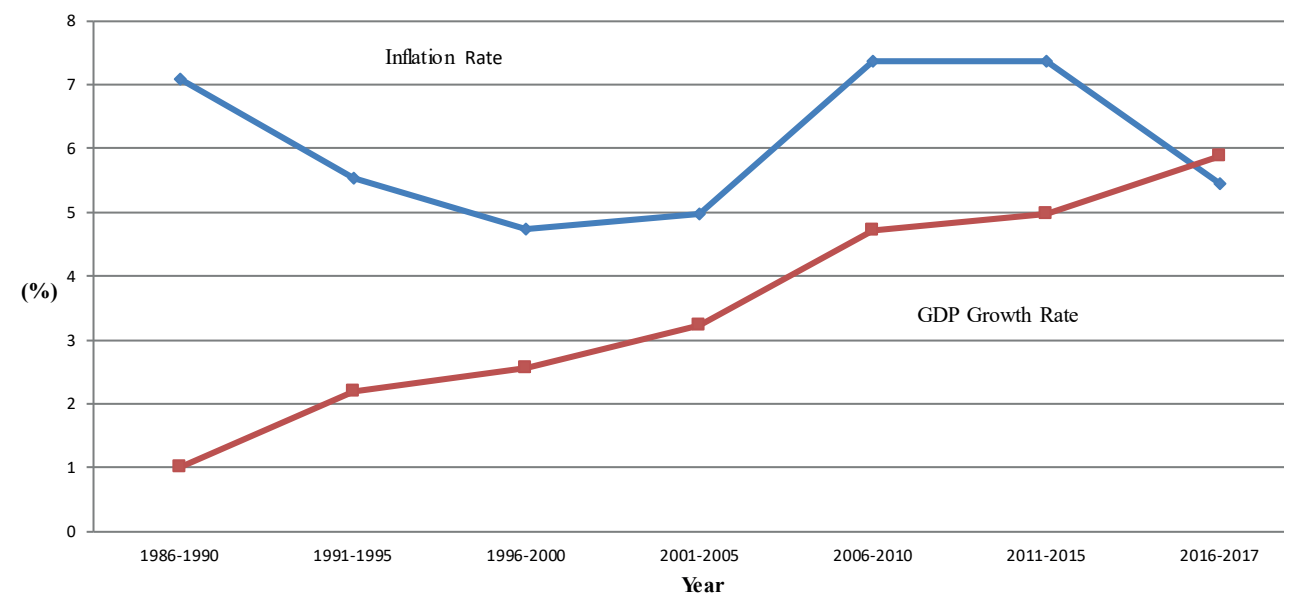

Source: World Bank database (2018). 
Revisiting inflation and growth nexus in Bangladesh: an asymmetric cointegration based on non-linear ARDL approach

Over the study period, the following graph describes the historical movement of the rate of inflation and real GDP growth rate for Bangladesh. However, any conclusion based on the graphical.

Assessment of Figure 2 would be an unwise conclusion; Figure 2 explains a positive connection between the crucial macroeconomic indicators of the economy of Bangladesh during the study period. Three times two-digit inflation has been practised in the economy of Bangladesh throughout the sample period. However, an inverse relationship between two variables is observed in the first half of the sample period.. In contrast, a positive relationship is found in the latter part of the sample period.

Figure 2. Inflation and GDP per capita Growth Rates (1986-2017)

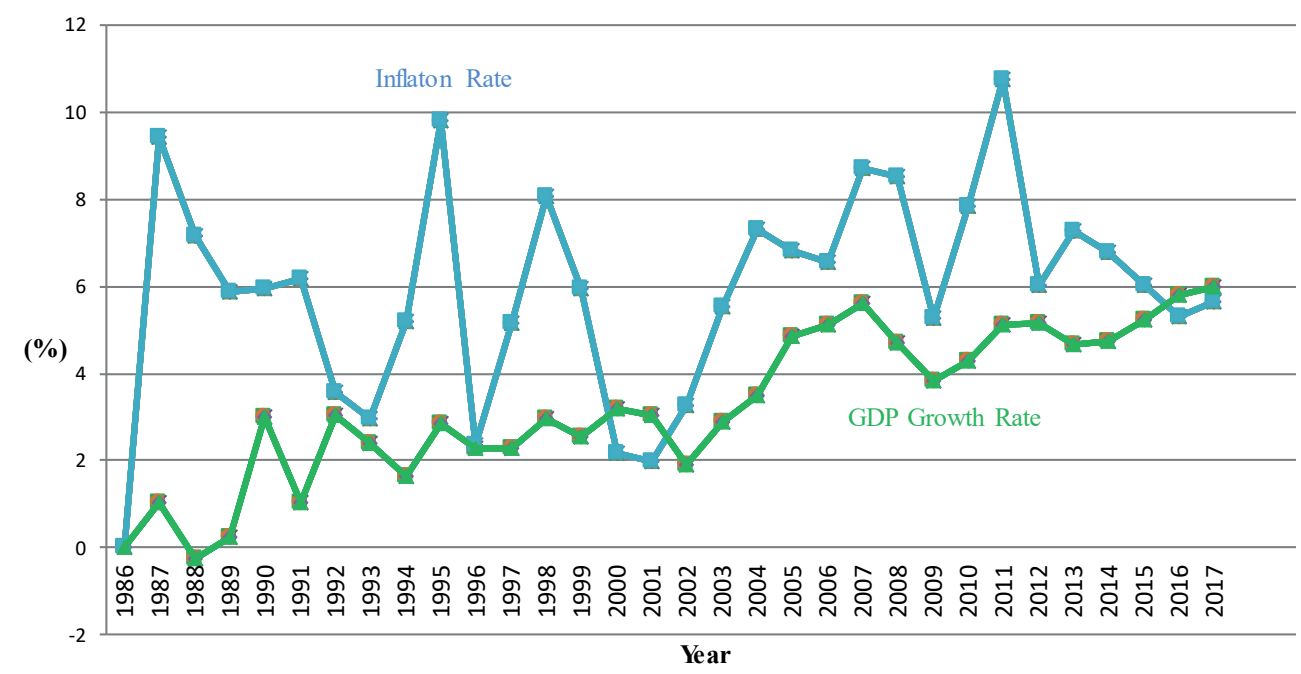

Source: World Bank database (2018).

\section{REVIEW OF EMPIRICAL STUDIES ON INFLATION-GROWTH NEXUS}

This section reviews some empirical studies conducted on cross country as well as country-specific. Using time series and panel data over different periods, various empirical studies examined the relationship between inflation and GDP growth. Most of these works have been employed internationally. To develop objectives in 
the case of Bangladesh, we have critically reviewed and presented a brief literature review of some important empirical studies.

Empirically, the inflation-growth nexus shows both positive and negative relationships through various studies conducted in many countries. Eventually, the theoretical conclusion of these studies reveals a threshold level of inflation beyond which inflation has a significant effect on growth. However, the threshold level varies across the countries.

Using the OLS technique, Sarel (1996) collected a sample of 87 countries over the period 1970-1990. He explored a negative impact of rising prices on growth with an asymmetric coefficient and revealed a statistically significant structure breakpoint. Structure break occurs in the output growth-inflation function when the annual average inflation rate is 8 percent. He mentioned that economic growth is negatively affected by inflation if the inflation rate is above 8 percent whereas below 8 percent, economic growth is positively influenced by inflation.

Ayyoub et al. (2011) had researched inflation-growth relation for Pakistan overtime period from 1972-73 to 2009-10. Using the OLS technique and time-series data, the study discovered an inverse association between inflation and economic growth. An absolute threshold level, on average, 7 percent, was found in the inflationgrowth relation function. They also explored that trying to control inflation below the threshold level was harmful to the economy of Pakistan, but it was beneficial to the economy above 7 percent.

Applying conditional least squares method and Non-Linear Least Squares (NLLS) , a study had been conducted by Khan and Ssnhadji (2001). They investigated the impact of the threshold point of inflation on economic growth for the economies of both developed and developing countries. The dataset used in this study for 1960 to 1998 covers the 140 industrialized and developing countries. The study explored the existence of a threshold point and that inflation beyond the threshold point harmed economic growth. Within the threshold point, inflation had a positive contribution to economic growth. The threshold level of inflation for developed nations had been found at $1-3$ percent and $11-12 \%$ for the developing nations, and these results had statistically significant. This study strongly supports the view that sustainable growth can be achieved through low inflation.

A recent work using annual time series data had been conducted by Paul, Kearney, and Chowdhury (1997) for 87 countries (48 developing and 29 developed 
Revisiting inflation and growth nexus in Bangladesh: an asymmetric cointegration based on non-linear ARDL approach

countries) over the range of period from 1960 to 1989 and explored no casual relation between inflation and economic growth in 40 percent countries. Further, they showed that in 20 percent of countries, there exists bidirectional causality. However, in the rest of the nations, a unidirectional relationship is found. A positive link between inflation and growth, more interestingly, was uncovered in the same case, but negative relation was explored in others.

Employing the ARCH (Autoregressive Conditional Heteroskedasticity) model, Sweidan, (2004) researched inflation-growth relation and uncertainty for Jordan's economy. The data set collected for this study covered the time range from 1970 to 2003. This empirical result showed that structure breakpoint occurs when the inflation rate is at $2 \%$, and after this point, inflation influences economic growth negatively.

S Ahmed \& Mortaza, (2010) examined the linkage between consumer price index (CPI) and real GDP for the economy of Bangladesh by applying yearly data over the 1981 to 2005 period. This study utilized co-integration and error correction model (ECM) and explored a base level of inflation at 6\% for Bangladesh. The empirical evidence in this paper showed a long-run negative linkage between Consumer Price Index and real Gross Domestic Products. In addition, this result had been found as statistically significant. This study showed that though inflation above the threshold level had an inverse impact on real GDP, below threshold level inflation had a positive contribution to economic growth.

Making use of yearly data from 1973 to 2000, a study had been performed by Mubarik \& Riazuddin (2005) on the inflation-growth nexus and investigated the threshold point for Pakistan. They claimed that there was a threshold point for the Pakistan economy at 9 percent. Above the threshold level, inflation had a negative contribution to GDP growth, but it had a positive contribution to growth below that level of inflation.

Another study was investigated by Munir, Mansur, \& Furuoka (2009) on inflation-GDP growth nexus for the economy of Malaysia. Applying the Threshold Autoregression (TAR) model and OLS technique, they had done this work with yearly data for the duration of 1970 to 2005. The authors claimed a particular threshold level (3.89\%) for Malaysia and state that the linkage between inflation and growth is not linear. The rate of inflation above the threshold level has a significant adverse impact on economic growth for the economy of Malaysia. There exists a substantial and positive nexus between inflation rate and GDP growth within the threshold 
level. The authors suggest that sustainable growth can be achieved by creating a low inflation environment.

Using yearly time series data of 24 years, Mallik and Chowdhury (2001) analyzed the growth-inflation link for Bangladesh, India, Sri Lanka, and Pakistan. They explored a positive correlation between the two concerned variables for four South Asian countries. This study used two econometric techniques (cointegration and error correction model). They propose that mild inflation is favourable to economic growth, and a further rapid growth rate leads to inflation. Authors find these economies on a Knife-edge. Finally, they recommended modest inflation for the economic growths of Bangladesh, Pakistan, Sri Lanka, and India.

Madurapperuma (2016) researched the inflation-growth nexus for Sri Lanka by utilizing annual data throughout 1988 to 2015. Error Correction Model (ECM) and Johansen cointegration test have been used in this article to explore a single threshold level for Sri Lanka. Moreover, the empirical evidence of this article claims that in Sri Lanka, there exists a statistically significant long-run negative relationship between economic growth and inflation.

In a recent study conducted in the case of D-8 countries, Aydin (2017) reveals that the threshold level is $12.88 \%$ for the effect of inflation on economic growth. On the other hand, Barcola and Kebalo (2018) found the threshold level lies between $8.01 \%$ and $15.46 \%$. That means, beyond this range, inflation does not affect economic growth. Another recent study conducted in the Southern African Development Community consists of 10 countries, Omay et al. (2018) found a threshold level between $12 \%$ and $32 \%$ determined endogenously.

Summarizing the literature review, a common thing has been noticed: most reviewed studies have discovered symmetric relations. But it always does not maintain a symmetry relation between two macroeconomic variables in the real world (Shin et. al., 2014; Ibrahim, 2015; Abdlaziz, Rahim, \& Adamu, 2016). These reviewed articles have explored the same inflation coefficient for economic growth, whatever upward or downward movement in inflation.. All the studies conducted on the economic growth-inflation nexus have revealed symmetric or linear coefficients contradictory to the real world. The study's uniqueness is to fill the underlined gap by exploring the realistic factor for the economic growth-inflation relation. This study investigates both the long- and short-run asymmetric relationship between inflation rate and economic growth for Bangladesh. The Non-linear Autoregressive 
Revisiting inflation and growth nexus in Bangladesh: an asymmetric cointegration based on non-linear ARDL approach

Distributed Lagged (NARDL) model, a newly developed by Shin et al. (2014), has been used to investigate the long-run and the short-run relation between concerned variables. Moreover, current research incorporates updated data from 1986 to 2017 and more observations than any others.

\section{METHODOLOGICAL APPROACH AND DATA ANALYSIS}

\section{Data Analysis}

All data of this study are composed of World Development Indicators (WB-2018). The data comprises an annual time series throughout the range of 1986 to2017 available while the study was conducted. the per capita GDP growth rate is the dependent variable, and the independent variable is the CPI (Inflation rate). The unit of measurement for all the variables is constant 2010 US dollars. The details of the data description and statistical descriptive is presented in the following section.

\section{Explained variable}

As the dependent variable, we used Gross Domestic Product (GDP) to capture economic growth. GDP per capita can capture more economic growth of a country than that of any other indicator. However, change in GDP ( $\triangle \mathrm{GDP})$ as used as log of GDP is used for the growth rate of the economy of Bangladesh. Gross Domestic Product (GDP) per capita, on the other hand, has been used by several studies as a dependent variable to explain economic growth (Shamim Ahmed, 2005; Ayyoub et al., 2011; Chimobi, 2010; Fountas, 2001; Girijasankar Mallik, Chowdhury, \& Wai, 2001; Mamo, 2012; Munir et al., 2009; Sweidan, 2004). GDPGR is composed of per capita Gross Domestic Product (GDP).

\section{Explanatory Variable}

A permanent increase in the general price level in an economy can be defined as the inflation. In this study, inflation rate is measured as the first different Consumer Price 
Index $(\Delta \mathrm{CPI})$. The consumer price index is only the explanatory variable of this study. ${ }^{1}$ The core objective of this study is to explore whether the inflation-growth nexus is linear or not and to investigate whether the relationship between the inflation rate and GDP growth rate is positive, negative, or neutral. The data of the variables are retrieved from the World Bank database indicator (2018). To find out the asymmetric relation, inflation has been divided into two variables: INF_P and INF_N. Here, INF_P and INF_N represent the partial sum of upward movement and the partial sum of downward movement in inflation, respectively. The economy observes different effectiveness of the positive and negative movement in inflation on economic growth. Table 1 shows the descriptive statistics of the variables.

Table 1

Descriptive statistics of the variables

\begin{tabular}{|c|c|c|c|c|c|c|c|}
\hline Variables & Obs & Mean & Std. Dev. & Maximum & Minimum & Jarque-Bera & Probability \\
\hline GDP & 32 & 602.1572 & 209.5646 & 1093.049 & 383.8125 & 4.191129 & 0.123001 \\
\hline CPI & 32 & 70.82884 & 40.51656 & 161.1360 & 24.28000 & 4.128841 & 0.126892 \\
\hline GDPGR & 31 & 3.376040 & 1.661729 & $5.982230(2017)$ & $-0.253127(1988)$ & 1.111706 & 0.573583 \\
\hline INF & 31 & 6.105148 & 2.198531 & $10.73548(2011)$ & $1.987296(2001)$ & 0.171085 & 0.918014 \\
\hline
\end{tabular}

Source: Authors' calculation based on World Bank database.

Note: the values of GDPGR $=\Delta$ GDP, INFLATION $=\Delta$ CPI.

\section{The Justification of NARDL Model}

A very moral person's negative change (bad task) may be surprising to you, but his positive change (excellent job) may not do the same. These two shifts in opposing routes (negative and positive) do not possess the identical capacity to influence you. However, the impacts are not symmetric (same) somewhat asymmetric (different). Asymmetry is a category of nonlinearity. The asymmetries are frequently practised in economic variables. In reality, asymmetry is a basis of the human condition since nonlinearity is widely observed in the social sciences (Shin et al., 2014).

1 In this empirical study, control variables such as gross capital formation and investment have not been inserted because of the unavailability of data for the economy of Bangladesh given time period. However, population growth, net export, and money supply (M2) have been found statistically insignificant for Bangladesh over the study period of 1986 to 2017, and further, they have been removed from the final regression model. There is a lack of a sufficient number of observations for all variables given the time frame. Finally, we are unable to insert many explanatory variables with-a-view to maintaining a reasonable degree of freedom. 
Revisiting inflation and growth nexus in Bangladesh: an asymmetric cointegration based on non-linear ARDL approach

A typical regression model based on time series data assumes a constant coefficient. A change (upward or downward) in the control variable has the same effect throughout time, which is not always the case. Furthermore, when a shock occurs, well-known cointegration techniques such as EG-ECM, VECM, Bound testing, ARDL, and others give a constant rate of adjustment (constant ECT) to long-run equilibrium. But this always cannot be real if there exists market friction (Dufrénot \& Mignon, 2002). Estimation of an asymmetry relationship with symmetric techniques appears to be biased and may lead the policy-maker to severe improper policy directions (Enders, 2008). The traditional cointegration test does not permit capturing the asymmetries in macroeconomic variables.

For this reason, different methods have been initiated to explain this asymmetry, such as Smooth transition regression ECM, Markov-switching ECM, threshold ECM, etc. However, the Non-linear Autoregressive Lagged (NARDL) Model recently proposed by Shin et al. (2014) includes asymmetries relationships both in the short and long run. Besides, the model takes the asymmetries in the dynamic modification. Furthermore, the model is applicable in a combined order of level and the first difference (Ibrahim, 2015).

A widespread concept is that the growth rate is not linearly affected by inflation (S Ahmed \& Mortaza, 2010). So, in the economy of Bangladesh, there is an asymmetric relationship between inflation and economic growth. Therefore, to explore asymmetries relationships both in the short and long run, we have applied the NARDL approach in this study.

\section{Empirical Model}

This study follows Abdlaziz et al. (2016) and Ibrahim (2015), where they have employed nonlinear ARDL models recently constructed by Shin et al. (2014). The nonlinear ARDL model adopted in this study incorporates both the short-run and the long-run asymmetric relationship between inflation and GDP growth in Bangladesh simultaneously. Using annual data from 1986 to 2017, we have also applied the NARDL model to explore both the long-run and short-run asymmetries for the economy of Bangladesh.

We specify the following regression model, followed by Shamim Ahmed (2005), for the relationship between inflation and economic growth.

$$
G D P G R_{t}=a+a_{1} I N F_{t}+U_{1 t}
$$


Where GDPGR denotes GDP growth rate, INF stands for the inflation rate, and $\mathrm{U} 1$ is a disturbance term. The growth rate is measured as $\Delta \mathrm{GDP}$, and the inflation rate is calculated as $\triangle \mathrm{CPI}$. We convert this model into NARDL form;

$$
G D P G R_{t}=\beta_{0}+\beta_{1} I N F_{-} P_{t}+\beta_{2} I N F_{-} N_{t}+{ }_{1 t}
$$

Where GDPGR denotes GDP growth rate, INF stands for the inflation rate, $U 1$ is a disturbance term, and $\beta=(\beta 0, \beta 1, \beta 2)$ are long-run coefficients that will be estimated later. INF_P and INF_N represent the partial sum of positive and negative changes in inflation, respectively.

$$
I N F_{-} P=\sum_{i=1}^{t} d I N F_{-} P_{i}=\sum_{i=1}^{t} \max \left(d I N F_{i}, 0\right)
$$

And

$$
I N F_{-} N=\sum_{i=1}^{t} d I N F_{-} N_{i}=\sum_{i=1}^{t} \min \left(d I N F_{i}, 0\right)
$$

At time $t, \beta_{1}$ represents the long-run relationship between economic growth and positive change in inflation, and $\beta_{2}$ represents the long-run relationship between economic growth and negative change in inflation. We can expand the concept of partial asymmetries to obtain the following asymmetric regression in the long-run as well as short-run:

$$
\begin{gathered}
D(G D P G R)=\beta_{3}+\beta 4 G D P G R_{t-1}+\beta_{5} I N F_{-} P_{t-1}+\beta_{6} I N F-N_{t-1}+ \\
\sum_{i=1}^{s} \delta_{i} d G D P G R_{t-1}+\sum_{i=1}^{s} \theta_{i} d I N F_{-} P_{t-i}+\sum_{i=1}^{s} \pi_{i} d I N F_{-} N_{t-i}+\mu_{2 t}
\end{gathered}
$$

Where $P$ and $s$ are lag order, $\beta_{1}\left(-\beta_{5} / \beta_{4}\right)$ and $\beta_{2}\left(-\beta_{6} / \beta_{4}\right)$ are long-run coefficients of "inflation rate increase" and "inflation rate decrease" respectively. $\sum_{i=1}^{s} \theta_{i}$ and $\sum_{i=1}^{s} \pi_{i}$ indicate the short-run effect of upward movement and downward movement in inflation on the regressand, respectively. $\mu_{2}$ is the error term. Before estimating the dynamic model in equation (5), we have to check the characteristic of the data, whether it is stationary or not. In this case, we assign underlined tests. The unit root or integration of data is tested by applying the three wide-used techniques; the Phillips-Perron (PP, 1988) test, the Augmented Dicky-Fuller (ADF, 1981) test and the Dicky-Fuller (DF, 1979) test.

At first, the relevant ADF, DF tests with a trend and without trend have been applied to conclude the non-stationary characteristic of the two variables in I(0) and I(1). The Dicky-Fuller (DF) test is based on the following equation: 
Revisiting inflation and growth nexus in Bangladesh: an asymmetric cointegration based on non-linear ARDL approach

$$
\Delta X_{t}=\chi+(\rho-1) X_{t-1}+\gamma T+U_{2 t} \quad[6]
$$

The ADF test is a modified version of the DF test, and the additional extension of the ADF test is the lagged values of the dependent variables based on the estimation given below:

$$
\Delta X_{\mathrm{t}}=\chi+(\rho-1) X_{t-1}+\gamma T+2 \Delta X_{t-1}+U_{3 t}
$$

Since it is widely believed that in raw data of economic time series variables, heteroskedasticity and non-normality are not considered both in the DF and the ADF tests, the PP test has been employed in this case. Moreover, when the underlined time series has a serial correlation and a structural break, the PP test is more applicable than the ADF test. Hence, over the DF and the ADF tests, the PP test gives a robust estimation. The PP test is established on the equation written below:

$$
\Delta X_{t}=\chi+(\rho-1) X_{t-1}+\gamma(t-T / 2)+\psi \Delta X_{t-1}+U_{4 t}
$$

The null hypothesis of non-stationary is tested applying the t-statistic along with critical values calculated by MacKinnon (1991). The null hypothesis that is GDPt* and CPIt* are non-stationary and get rejected if $\rho$ is smaller than one and statistically significant for either one. In equations (6), (7), and (8), is indicated first difference, and $U 2 t, U 3 t$, and $U 4 t$ are the stationary random error terms. Each test is executed for both GDPt* and CPIt* by replacing Xt in equations (6) (for the DF test), (7) (for the ADF test), and (8) (for the PP test). Lastly, the above unit root tests have been carried out for residuals of equations (5), i.e., $2 t$. Thus we conclude, the two series, GDPGR and INF, are cointegrated once errors are found I(0). Further, it indicates the evidence for the existence of a valid and stable long-run relationship between two variables.

An asymmetric cointegration approach based on NARDL (Shin et al., 2014) is applied to confirm the integration order of time series data. To complete this work, we have to maintain a few essential steps. Firstly, we use a nonlinear ARDL model through the Stepwise Least Squares method to estimate the equation (5) to explore the results of the final equation of the NARDL model by eliminating the irrelevant lags. Next, we use the bound test approach to check long-run integration among concerning variables and test the joint null hypotheses of $\beta 4=\beta 5=\beta 6=0$. We use the Wald test to check the long-run asymmetry between inflation and growth rate in the final step. 


\section{RESULTS AND THE DIAGNOSTIC TESTS}

\section{Unit Root Test and BDS Test}

Any analysis involved with time-series data requires checking the order of integration. Because there is a higher possibility of a spurious outcome from the regression. A time series $\mathrm{X}$ will be stationary when the mean and variance of this series do not vary throughout the time range, and the covariance between two observations differs not on the exact time when the variance is calculated rather barely on the difference between the two time periods (Gujarati, 2009). There are many ways to examine the stationarity of data. Among the various tests for a unit root, the three standard approaches have been widely used to test the stationary of time series variables. The Phillips-Perron (PP 1988), the Augmented Dicky-Fuller (ADF, 1981) test, the DickyFuller (DF, 1979) test have been applied in this section (S Ahmed \& Mortaza, 2010; Shamim Ahmed, 2005; Khan et al., n.d.; Mahmud, 1997). The optimum lag structure for DF and ADF tests are selected relied on the Schwarz information criterion (SIC) and for PP test is an automatic selection founded on Newey-West Bandwidth.

This test's decision criterion is that the null hypothesis is rejected if the unit root test's p-value is less than $5 \%$. Otherwise, the null hypothesis cannot be rejected. The null hypothesis would be rejected if the variable had no unit root. It denotes that the data are static. The result of these data would not be spurious if they were confirmed to be steady at the level (Gujarati, 2009).

Table 2.

The Results of the Unit Root Test of All Variables

\begin{tabular}{|c|c|c|c|c|c|c|c|}
\hline \multirow{2}{*}{ Variables } & \multicolumn{2}{|c|}{ DF } & \multicolumn{2}{c|}{ ADF } & \multicolumn{2}{c|}{ PP } & \\
\cline { 2 - 8 } & $\begin{array}{c}\text { Without } \\
\text { trend }\end{array}$ & $\begin{array}{c}\text { With } \\
\text { trend }\end{array}$ & $\begin{array}{c}\text { Without } \\
\text { Trend }\end{array}$ & $\begin{array}{c}\text { With } \\
\text { trend }\end{array}$ & $\begin{array}{c}\text { Without } \\
\text { trend }\end{array}$ & $\begin{array}{c}\text { With } \\
\text { trend }\end{array}$ & Decision \\
\hline GDPGR & $\mathrm{I}^{*}(1)^{*}$ & $\mathrm{I}(0)^{*}$ & $\mathrm{I}(1)^{*}$ & $\mathrm{I}(0)^{*}$ & $\mathrm{I}(0)$ & $\mathrm{I}(0)^{*}$ & $\mathrm{I}(0)$ \\
\hline INF & $\mathrm{I}(0)^{*}$ & $\mathrm{I}(0)^{*}$ & $\mathrm{I}(0)^{*}$ & $\mathrm{I}(0)$ & $\mathrm{I}(0)^{*}$ & $\mathrm{I}(0)$ & $\mathrm{I}(0)$ \\
\hline
\end{tabular}

Note: SIC is used to select the optimum lag. $\left(^{*}\right)$ indicates a $1 \%$ level of significance.

Source: Author's calculations.

Table- 2 shows the result for the unit root test. The output of unit root tests indicates that GDP growth rate and inflation rate, on the other hand, are stationary at a $1 \%$ significance level. The nonlinear ARDL model allows the variables both $\mathrm{I}(0)$ and I(1). The GDP growth rate and the inflation rate are found to be I(0). It implies that not a single variable is I(2). Consequently, we can keep on the nonlinear 
Revisiting inflation and growth nexus in Bangladesh: an asymmetric cointegration based on non-linear ARDL approach

autoregressive distributed lagged (NARDL) approach. The following section describes the empirical result of the nonlinear ARDL model. Table-3 represents the results of structural break BDS that also necessitates NARDL model.

Table-3.

\section{BDS test for structural break}

\begin{tabular}{|c|c|c|c|c|c|c|}
\hline BDS Statistic & \multicolumn{6}{|c|}{ Embedding dimensions=m (probability) } \\
\hline Variable & $\mathrm{m}=2$ & $\mathrm{~m}=3$ & $\mathrm{~m}=4$ & $\mathrm{~m}=5$ & $\mathrm{~m}=6$ & Raw epsilon \\
\hline GDPGR & 0.0000 & 0.0000 & 0.0000 & 0.0000 & 0.0000 & 0.025556 \\
\hline INFLA & 0.0135 & 0.0062 & 0.0188 & 0.0484 & 0.1456 & 3.540428 \\
\hline
\end{tabular}

Source: Author's calculations.

\section{The Output of the Nonlinear ARDL Model}

In this stage, we regress nonlinear autoregressive distributed lagged models (NARDL) to discover the long-run and short-run relation between the two macroeconomic variables for Bangladesh. Table-4 presents the empirical result obtained from the nonlinear ARDL model by using econometric software Eviews-9. Since this study has been conducted with variables that are defined as a rate, the interpretations of those coefficients are percentage point (Hasan, 2017).

Long-run estimated regression:

$$
\mathrm{GDPGR}^{2}=3.767306+0.397079 \text { INF_P }+0.305093 \text { INF_N }
$$

From the above results, important figures are bolded and it reveals that the inflation rate has a significantly positive effect on the growth rate of per capita Gross Domestic Product (GDP). The NARDL model states that the growth rate would increase by 3.77 percent point without changing in inflations.

Furthermore, a 1 percent point positive change in the inflation rate would lead to, on average, a 0.397 percent point increase in the growth rate of per capita GDP in the long run. On average, 0.31 percent point a decrease in per capita GDP growth rate due to a 1 percent point negative change in the inflation rate in the long run. This estimated result indicates a positive relationship between inflation and economic growth in the economy of Bangladesh. These results have statistically significant at a $1 \%$ significance level. This positive relationship between two variables is also

2 Here, the long-run coefficients of Non-Linear Autoregressive Distributed Lagged (NARDL) model are 3.767306 $=(-4.674172 /-1.240720), 0.397079=(-0.492665 /-1.240720)$, and $0.305093=(-0.378535 /-1.240720)$. 
Table 4.

The results of Nonlinear ARDL model

\begin{tabular}{|c|c|c|c|c|}
\hline \multicolumn{5}{|c|}{$\begin{array}{l}\text { Method: Stepwise Regression } \\
\text { Sample Range: } 1986 \text { to } 2017 \\
\text { Selection method: Uni-directional } \\
\text { Stopping criterion: P-value }=0.05\end{array}$} \\
\hline Variables & Coefficient & Std. Error & t-Statistic & Probability \\
\hline Intercept & 4.674172 & 0.838066 & 5.577330 & 0.0000 \\
\hline GDPGR $(-1)$ & -1.240720 & 0.217582 & -5.702316 & 0.0000 \\
\hline INF_P $(-1)$ & 0.492665 & 0.094878 & 5.192617 & 0.0001 \\
\hline INF_N $(-1)$ & 0.378535 & 0.083614 & 4.527166 & 0.0003 \\
\hline DGDPGR $(-4)$ & -0.252955 & 0.084337 & -2.999323 & 0.0085 \\
\hline DINF_P (-2) & -0.304460 & 0.071832 & -4.238485 & 0.0006 \\
\hline DINF_P $(-1)$ & -0.499337 & 0.138146 & -3.614566 & 0.0023 \\
\hline DINF_P & 0.274619 & 0.090275 & 3.042036 & 0.0078 \\
\hline DGDPGR $(-2)$ & 0.298960 & 0.117422 & 2.546032 & 0.0216 \\
\hline DGDPGR (-1) & 0.692719 & 0.198895 & 3.482846 & 0.0031 \\
\hline R square & 0.825287 & \multicolumn{2}{|c|}{ Adjusted R square } & 0.727011 \\
\hline Log-likelihood & -6.908748 & \multicolumn{2}{|c|}{ Std. Error. of regression } & 0.402338 \\
\hline F-statistic & 8.397636 & \multicolumn{2}{|c|}{ Sum squared resid } & 2.590010 \\
\hline Probability(F-statistic) & 0.000141 & \multicolumn{2}{|c|}{ Dependent variable } & GDPGR \\
\hline Durbin-Watson & 1.978464 & & & \\
\hline
\end{tabular}

Source: Author's calculations.

supported by the theory of Keynesian and neoclassical growth theories. This empirical result also supports the study conducted by Mallik et al. (2001). It is noticed that the growth rate response is more with a positive change in inflation than negative change because the coefficient of positive variation in inflation is more significant than that of negative change.

The estimated results of the NARDL model also provide evidence for shortrun asymmetry. It is noticed that the upward movement in inflation is statistically significant, while the downward shift in inflation is statistically insignificant. The coefficient of a short-run nexus between growth rate and upward movement in inflation is positive. It indicates that an instant 1 percent point upward change in inflation increases the economic growth rate by 0.27 percent in the short-run.

This model is the finest fit as the value of adjusted $\mathrm{R}^{2}$ and $\mathrm{R}^{2}$ are very high (0.727011, and 0.8253). The corresponding probability value is much small, and the F-statistic value is also large and statistically significant. The Durbin-Watson value is close to 2 . 
Revisiting inflation and growth nexus in Bangladesh: an asymmetric cointegration based on non-linear ARDL approach

Before going to the decision rule regarding the estimated coefficients, we need to test whether the variables are cointegrated or not. The next section presents the result of the asymmetric cointegration test.

\section{Asymmetric Cointegration}

This part of the study describes the result of asymmetric cointegration between variables. The estimated coefficient of the NARDL model will be spurious if variables are not cointegrated. This asymmetric cointegration technique under the nonlinear ARDL model has been proposed by Shin et al (2014). They have recommended applying the joint null hypothesis of level variables and evaluating the bound test's critical values proposed by (Pesaran, Shin, \& Smith, 2001). If the estimated value of F-statistics is obtained as more significant than the upper critical value, it confirms cointegration. If the F-value is closer to zero than the lower critical value, then there is no cointegration. If the F-value falls between the upper and lower critical values, then no conclusion can be drawn. Table- 5 shows the Wald test for asymmetry cointegration and Pesaran bound test critical values. The following result of the Wald test is obtained from using analytical software Eviews-9.

Table 5.

The Outcomes of Wald test for long-run Cointegration

\begin{tabular}{|c|c|c|c|}
\hline \multicolumn{4}{|c|}{ Wald Test: } \\
\hline & \multicolumn{2}{|c|}{ Equation: Nonlinear ARDL_Model } & \multirow[b]{2}{*}{ Probability } \\
\hline Test Statistic & Value & $\mathrm{df}$ & \\
\hline F-statistic & 11.23185 & $(3,16)$ & 0.0003 \\
\hline Chi-square & 33.69554 & 3 & 0.0000 \\
\hline Bound test critical values: & \multicolumn{2}{|c|}{$\mathrm{I}(0) \quad \mathrm{I}(1)$} & \multirow{4}{*}{$\mathrm{k}=1$} \\
\hline $1 \%$ & 6.68 & 7.84 & \\
\hline $5 \%$ & 4.94 & 5.73 & \\
\hline $10 \%$ & 4.04 & 4.78 & \\
\hline
\end{tabular}

Note: $k$ represents the number of regressors. And bound test critical values for unrestricted and no trend.

Source: Author's calculations.

From table-05, it is clear that the null hypothesis is rejected because of being a greater calculated F-statistic than bound test critical value. At a $1 \%$ significance level, the upper bound of critical values is 7.84 , whereas the calculated 
F-statistic (11.23185) is larger than the critical value. It means that the null hypothesis claiming no asymmetric cointegration is rejected. This indicates strong evidence for asymmetric cointegration between two variables at a $1 \%$ significance level in the long run. Now it is time to check asymmetry between positive and negative changes in inflation. The upcoming section describes the result of the asymmetry test.

\section{The Evidence for Asymmetry Relation}

This section describes the presence of asymmetry in the underlying model. The estimated result of the nonlinear autoregressive distributed lagged (NARDL) model claims that positive change and negative change in inflation have a long-run positive effect on economic growth in the economy of Bangladesh. Now the question is what they are statistically different. An asymmetry test investigates whether the coefficients are equal or not. If they are not identical, there is evidence of asymmetry; otherwise, it would not be. To test the long run asymmetry in Eviews-9, we use the Wald test.

$$
\begin{aligned}
& \text { Here, } \\
& \mathrm{H}_{0}:-\mathrm{C}(3) / \mathrm{C}(2)=-\mathrm{C}(4) / \mathrm{C}(2) \text { (Symmetry) and } \\
& \mathrm{H}_{\mathrm{A}}:-\mathrm{C}(3) / \mathrm{C}(2) \neq-\mathrm{C}(4) / \mathrm{C}(2) \text { (Asymmetry) }
\end{aligned}
$$

The null hypothesis would be rejected in case of a P-value lower than 5\%; otherwise, it would be accepted. Table- 6 shows the Wald test output for the asymmetry test by using statistical software EViews.

\begin{tabular}{|c|c|c|c|}
\hline & Wald Test: & & \\
\hline & \multicolumn{2}{|c|}{ Equation: Nonlinear ARDL_Model } & \\
\hline Test Statistic & Value & df & Probability \\
\hline t-statistic & 9.541593 & 16 & 0.0000 \\
\hline F-statistic & 91.04199 & $(1,16)$ & 0.0000 \\
\hline Chi-square & 91.04199 & 1 & 0.0000 \\
\hline \multicolumn{4}{|c|}{ Null Hypothesis: - C (3) / C (2) = - C (4) / C (2) } \\
\hline & \multicolumn{2}{|c|}{ Null Hypothesis Summary: } & \\
\hline Normalized Restriction $(=0)$ & & Value & Std. Err. \\
\hline$-C(3) / C(2)+C(4) / C(2)$ & & 0.091987 & 0.009641 \\
\hline
\end{tabular}

Table 6.

The Results of Wald test for Asymmetry

Source: Author's calculations. 
Revisiting inflation and growth nexus in Bangladesh: an asymmetric cointegration based on non-linear ARDL approach

It is noticed in Table- 6 that the null hypothesis of symmetry is rejected because the p-value is less than 5 percent. The result of the Wald test reveals that an asymmetry in the long-run impact of inflation exists there in the economy of Bangladesh. It is shown that the growth rate is more influenced by positive change than the negative change in inflation. This result suggests that the inflation controlling policy taken by the Bangladesh bank would not be beneficial to the economy.

Finally, for the robustness of the results, we need to check various diagnostic statistic tests. The next section describes the stationary test for the residual of the estimated model.

\section{Stationary Test for Residuals of NARDL Model}

The unit root test for residuals of a regression model checks whether the regression model results are spurious. If the residuals of the regression model are nonstationary at the level, it implies that the output of the regression would be illogical or spurious. The regression result would be logical or not spurious if the residuals of the regression model are stationary at level.

Here,

$\mathrm{H}_{0}=$ the residual has a unit root or non-stationary, and

$\mathrm{H}_{\mathrm{A}}=$ the residual has no unit root or stationary.

The conclusion-making rule of this experiment is that the null hypothesis gets rejected if the derived ADF test's $p$-value becomes lower than $5 \%$. We cannot reject the null hypothesis otherwise. The null hypothesis would be rejected if the variable had no unit root and the the data are stationary.

The decision rule regarding the regression model is that if the residuals of the regression model regressed on non-stationary time series data are stationary in level, the regression results would not be a spurious or non-sense regression.

Table 7.

The results of the Stationary test for residuals

\begin{tabular}{|c|c|c|c|}
\hline \multicolumn{2}{|c|}{ Augmented Dickey-Fuller test statistic } & t-Statistic & Probability* \\
\cline { 2 - 3 } & 5\% level & -4.660068 & 0.0053 \\
\hline Test critical values: & -3.603202 & \\
\hline
\end{tabular}

*MacKinnon (1996) one-sided p-values. Source: Using EViews 9 and data collected from WB (2018) Source: Author's calculations. 
From Table-7, it is clear that the $p$-value of the t-statistic is less than $5 \%$. It indicates the rejection of the null hypothesis. The rejection of the null hypothesis means that the residuals of the regression model are stationary. A figure contained residuals distribution is inserted into the appendix (you can see). The results of the regression model will not be spurious because of being stationary the residuals of the NARDL regression model. The nonlinear ARDL regression model is not only a long run but also a short run regression model. In the following section, the serial correlation test for the NARDL regression model is disclosed.

\section{Serial Correlation Test}

The autocorrelation or the serial correlation implies to the correlation in the residuals of a regression model. The Breusch-Godfrey Serial Correlation Lagrange Multiplier (LM) test is used in this study to test serial correlation by using EViews-9.

Table 8.

Results for Autocorrelation of NARDL

\begin{tabular}{|c|c|c|c|}
\hline & \multicolumn{2}{|c|}{ Breusch-Godfrey Serial Correlation LM Test: } & \\
\hline F-statistic & 0.016866 & Prob. F (1,15) & 0.8984 \\
\hline Obs*R-squared & 0.029201 & Prob. Chi-Square (1) & 0.8643 \\
\hline
\end{tabular}

Source: Author's calculations.

Here, because the p-value is greater than $5 \%$, the null hypothesis cannot be rejected. This means that no serial correlation exists there in the Nonlinear ARDL regression model. In addition to this, it explains that the results obtained from NARDL Regression are not spurious or non-sense.

\section{Heteroskedasticity Test}

The unequal variances of the residuals can be defined as heteroskedasticity. The estimated coefficient of regressors is obtained to be statistically insignificant with heteroskedasticity (Gujarati, 2009). To identify the heteroskedasticity for the Nonlinear ARDL regression model, Breusch-Pagan-Godfrey heteroskedasticity and Autoregressive Correction Heteroskedasticity (ARCH) tests have been used. 
Revisiting inflation and growth nexus in Bangladesh: an asymmetric cointegration based on non-linear ARDL approach

Null hypothesis $\mathrm{H}_{0}$ : No heteroskedasticity is there and

Alternative hypothesis $\mathrm{H}_{\mathrm{A}}$ : Heteroskedasticity is there.

Provided that the subsequent $p$-value of observing $\mathrm{R}$ square is larger than $5 \%$, the decision rule is that the null hypothesis cannot be rejected. The result for heteroskedasticity has been presented in Table 9 below.

Table 9.

Results for Heteroskedasticity of NARDL

\begin{tabular}{|c|c|c|c|}
\hline \multicolumn{4}{|c|}{ Heteroskedasticity Test: Breusch-Pagan-Godfrey } \\
\hline F-statistic & 0.828564 & Prob. F $(9,16)$ & 0.6003 \\
\hline Obs*R-squared & 8.265477 & Prob. Chi-Square (9) & 0.5076 \\
\hline Scaled explained SS & 5.161601 & Prob. Chi-Square (9) & 0.8200 \\
\hline \multicolumn{4}{|c|}{ Heteroskedasticity Test: Autoregressive Correction Heteroskedasticity (ARCH) } \\
\hline F-statistic & 0.484701 & Prob. F $(1,23)$ & 0.4933 \\
\hline Obs*R-squared & 0.515976 & Prob. Chi-Square (1) & 0.4726 \\
\hline
\end{tabular}

Source: Author's calculations.

\section{Result for Normality Test}

A normality test is used to determine if the residuals follow a normal distribution or not. If the distribution of the residual is not normal, even if the derived t-ratios appear to be good, the choice may not be acceptable. This test's null hypothesis is that the residuals series is normally allocated, whereas the alternative hypothesis is not. The outcomes of the normality test for the model's residuals are shown below.

According to the judgment, the null hypothesis cannot be rejected if the Jarque-Bera statistic's related p-value is more than $5 \%$. The null hypothesis would be rejected otherwise. The Jarque-Bera (JB) test statistic is the proper normality test statistic in this case. The figure shows the results of the normality test produced with the statistical software Eviews-9.

Figure 3 shows that the Jarque-Bera value is 4.081367, and the corresponding probability value $(0.129940)$ is higher than $5 \%$. Eventually, at a $5 \%$ level of significance we cannot reject the null hypothesis given the Jarque-Bera statistic. So, over the study periods, the errors of the Nonlinear ARDL regression model are normally distributed, and a conclusion based on Nonlinear ARDL regression is acceptable. In the following section, the model specification error test is executed. 
Figure 3. Result for the normality test of NARDL Regression model (the Jarque-Bera test)

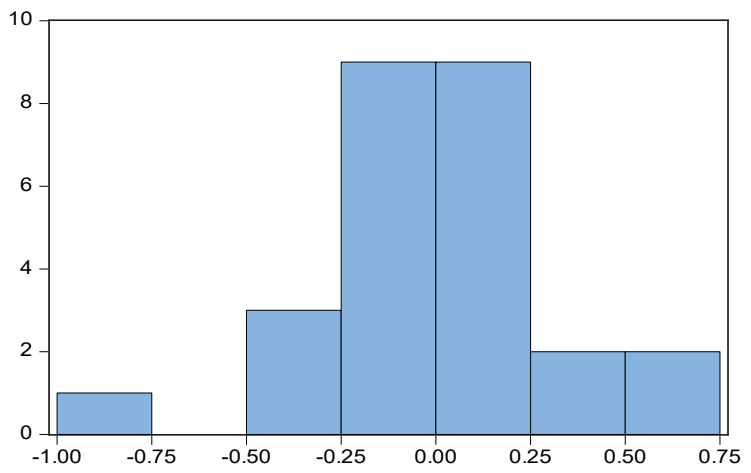

\begin{tabular}{|lc|}
\hline \multicolumn{2}{|l|}{ Series: Residuals } \\
Sample 1992 2017 \\
Observations 26 \\
Mean & $2.95 e-16$ \\
Median & 0.017263 \\
Maximum & 0.565502 \\
Minimum & -0.946561 \\
Std. Dev. & 0.321870 \\
Skewness & -0.721554 \\
Kurtosis & 4.298019 \\
& \\
Jarque-Bera & 4.081367 \\
Probability & 0.129940 \\
\hline
\end{tabular}

Source: Author's calculations.

\section{Regression Specification Error Test}

Whether the NARDL regression model is appropriately specified or not, The Regression Specification Error Test (RESET) is applied that was formed by Ramsey (1969) to identify the specification error in a regression model.

Decision-making practice is that the null hypothesis would be rejected if the subsequent $p$-value of F-statistic is lower than 5\%; outcomes of the Ramsey RESET test derived using EViews 9 are shown in Table 10 below.

From the above result, it is impossible to reject the null hypothesis at a $5 \%$ significance level. So, it is possible to decide that the nonlinear ARDL regression model is Table 10.

Results for Regression Specification Error Test of NARDL

\begin{tabular}{|c|c|c|c|}
\hline & Value & $\mathrm{df}$ & Probability \\
\hline t-statistic & 1.395541 & 15 & 0.1832 \\
\hline F-statistic & 1.947535 & $(1,15)$ & 0.1832 \\
\hline Likelihood ratio & 3.173877 & 1 & 0.0748 \\
\hline F-test summary: & & & \\
\hline & Sum of Squares & $\mathrm{df}$ & Mean Squares \\
\hline Test SSR & 0.297632 & 1 & 0.297632 \\
\hline Restricted SSR & 2.590010 & 16 & 0.161876 \\
\hline Unrestricted SSR & 2.292377 & 15 & 0.152825 \\
\hline
\end{tabular}

Source: Author's calculations. 
Revisiting inflation and growth nexus in Bangladesh: an asymmetric cointegration based on non-linear ARDL approach

free from a specification error problem. This model is well specified. The model stability test (CUSUM Test) for the NARDL regression model is inserted in the following figure.

\section{Structural Stability Test}

To check the structural stability test, recursive estimation has been applied. There are two types of tests in recursive estimation. The Cumulative Sum and Cumulative Sum of squares test are used to detect the structural stability of the nonlinear ARDL model.

Null hypothesis $\mathrm{H}_{0}$ : There is no structural change in parameters.

Alternative hypothesis $\mathrm{H}_{\mathrm{A}}$ : There is a structural change in parameters.

The results for the structural stability test have been shown by using the software EViews 9 in figure 4.

Figure 4. Structural Stability Test (CUSUM Test)

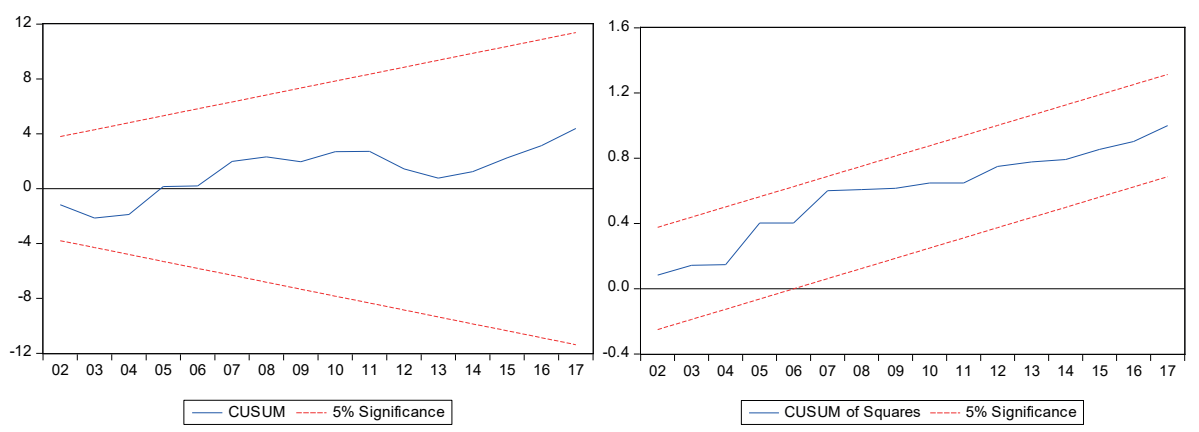

Source: Author's calculations

The decision rule is that we cannot reject the null hypothesis if the Cumulative Sum (CUSUM) line lies between two critical lines at a 5\% significance level. Otherwise, the null hypothesis would be accepted. In this case, we cannot reject the null hypothesis, which implies that the NARDL model is structurally stable over study time.

\section{ANALYSIS OF THE FINDINGS OF THIS STUDY}

The primary objective of this research is to re-visit the nature of the connection between inflation and economic growth for Bangladesh and investigate asymmetric cointegration between two variables both in the long- and the short run. 
The nonlinear ARDL regression model results show a significantly positive relationship between inflations and per capita GDP growth in the long run and in the short run. The result from the regression model states that there is an asymmetric cointegration between inflation and economic growth. If inflation rises by 1 percent point, the growth rate on average will increase by 0.397 percent point in the long run. In contrast, a one percentage point decrease in inflation would lead to, on average, 0.31 percent point decrease in economic growth in the long-run. These results are discovered to be statistically significant at 1 percent level of significance. In the short run, only positive change in inflation is found to be statistically significant. Whereas instantly 1 percent point positive change in inflation would lead to an average 0.27 percent point rise in economic growth. It is noticed that the growth rate is more influenced by positive change than that of adverse change in inflation. The coefficient of positive change in inflation is larger than that of negative change. The independent variable can explain the dependent variable by 82.53 percent in this model, making it the best fit. The F-statistic result is also large; however, the probability value is significantly lower. There is no serial association, and the F-statistic figure is statistically valid.

The first objective of this study was to investigate the long-run and the shortrun cointegration between economic growth and inflation. And whether it is positive, negative or neutral. There is a wide belief that inflations harm the economic growth of Bangladesh. But we have found that inflation has a positive impact and can affect the economic growth of Bangladesh significantly both in the long- and in the shortrun. The Keynesian and the neo-classical theory support this result. The results of this study are also identical to the $r$ for Bangladesh conducted by Malik et al. (2001) and Paul et al., (1997). On the other hand, Ahmed et al. (2005) explored a negative nexus between inflation rate and economic growth rate for Bangladesh.

We find that the growth rate is more influenced by a positive change in inflation than that of a negative one. Where economic growth would, on average, increase by 0.397 percent point due to a 1 percent point positive change in inflation, but economic growth would, on average, decrease by 0.31 percent point because of being a 1 percent point negative change in inflation. On the other hand, economic growth would, on average, increase by 0.27 percent point due to 1 percent point positive change in inflation in the short-run. Still, an adverse change in inflation is statistically insignificant.

The second objective of this study is to re-investigate the nature of the relationship between economic growth and inflation for Bangladesh. And whether it is symmetric or asymmetric? We have found an asymmetric relation between inflation and economic 
Revisiting inflation and growth nexus in Bangladesh: an asymmetric cointegration based on non-linear ARDL approach

growth. The rejections of the null hypothesis of equal coefficients of positive change and negative change in inflation are the evidence of asymmetric relation. It is also found that positive change in inflation can affect economic growth more than that negative change in the long run. But in the short-run, the negative change in inflation cannot affect economic growth where positive change can do. Therefore, this study states an asymmetric (Nonlinear) relation between inflation and economic growth for Bangladesh.

Some policy recommendations for effective monetary policy and sustainable economic growth in Bangladesh can be put forward from the study. These results seem to be crucial for policy implementations. These results provide information to not only policymakers but also development agencies. Firstly, the inflation rate does not increase the level of wages and salaries. It would lead to falling the purchasing power of currencies. Second, Inflation can lead to an increase in the living cost by reducing purchasing power for households. Therefore, during the period of inflation, investors want to invest money to earn a margin to recover the cost of lowering the value of money. Thus, economic growth increase through the growth of investment.

In conclusion, we have found that inflation and economic growth maintain a positive nexus, and inflation can boost Bangladesh's economic growth. Inflation can be treated as one of the crucial determinants of Bangladesh's economic growth (GDP).

\section{CONCLUSIONS}

The main goal of our study was to explore the two main issues of inflation and economic growth from the perspective of Bangladesh. The first issue was to investigate the long- and the short-run relation between economic growth and inflation. And to examine whether the relationship is positive, negative or neutral. The second objective of the is study was to re-inspect the direction of the relationship between these two variables for Bangladesh, whether it is symmetric or asymmetric.

We have employed a Nonlinear ARDL approach to examine those issues from 1986 to 2017. The data are composed of the World Bank database indicator (2018). The empirical evidence demonstrates a positive relationship between inflation and economic growth in both the country's short- and long run, and those relations are derived from being statistically significant. Further, those results are identical to the study conducted by Mallik and Chowdhury (2001) and supported by the theories of the Keynesian and the neoclassical growth model. In the long run, a 1\% point rise in inflation leads to change the economic growth by on average 0.397 percent 
point and a decrease in the inflation by $1 \%$ point cause the economic growth by on average 0.31 percent point. But in the short-run, a 1 percent point increase in inflation would lead to, on average $0.27 \%$ increase in the economy and an adverse change in inflation has no statistical meaning. On the other hand, this study finds an asymmetric relationship between inflation and economic growth for Bangladesh. It is also found that a positive change in inflation can affect economic growth more than that of a negative one.

These results are crucial for policy implementations. These results provide information to not only policymakers but also to the development agencies. Inflation can lead to an increase the living cost by reducing purchasing power for a household. Therefore, during the period of inflation, investors want to invest more money to earn a margin to recover the cost of reducing the value of money. Thus, economic growth increase through the growth of investment. Our study suggests that inflation can boost up the economic growth for Bangladesh and can be treated as one of the crucial determinants of Bangladesh's economic growth (GDP).

This study finds that inflations have a positive relationship with the economic growth of Bangladesh in either the long run or short run based on the time series data over the time from 1986 to 2017. Those results are validated by previous studies (Mallik et al. 2001, Paul et al. 1997). The results of this study go to the opposite of the traditional belief that inflation is harmful to economic growth (Shamim Ahmed, 2005). Inflation can lead to an increase the living cost by reducing purchasing power for households. Therefore, during the period of inflation, investors want to invest money to earn a margin to recover the cost of lowering the value of money. That's why economic growth increase through the growth of an investment.

The policymaker of Bangladesh should keep in mind that a tight inflation policy would be harmful to the economy rather than helpful. Zero inflation would discourage the group of investors from building up a new industry. During inflation time, the producer would cut down the size of labour because of maintaining the sufficient profit level. On the other hand, inflation can attract new investors to invest in the market as well as it also offers existing industries to expand their current scale of production. Finally, we seem to be that the economy of Bangladesh prefers moderate inflation to low inflation. Thus, Bangladesh can reach its optimum development goal through a sound monetary policy that tolerates average inflation in the economy. More specifically, inflation below $10 \%$ may accelerate the growth in Bangladesh. 
Revisiting inflation and growth nexus in Bangladesh: an asymmetric cointegration based on non-linear ARDL approach

For the economy of Bangladesh, the underlined issues are not captured by our study. To take a sound policy, additional studies are required on the following issues:

a. The connection between inflation and inflation uncertainty.

b. Factors influencing high inflationary pressure.

This study also recommends the necessity of advanced research on the relationship between inflation and economic growth in both the long and short run by adding more variables and updated data. The need for future study is that the nature of the economy is gradually changing with the change of the modern world.

\section{ACKNOWLEDGEMENTS}

The authors are grateful to the anonymous reviewers whose comments and suggestions helped a lot to improve the article. Moreover, the authors acknowledge the software supports provided by UniV to improve the language of the article.

\section{DECLARATION OF INTEREST CONFLICTS:}

The authors declare that they have no conflict of interest.

\section{REFERENCES}

1. Abdlaziz, R. A., Rahim, K. A., \& Adamu, P. (2016). Oil and Food Prices Cointegration Nexus for Indonesia: A Nonlinear Autoregressive Distributed Lag Analysis. International Journal of Energy Economics and Policy, 6(61), 82-87. Retrieved from http:\%5Cnwww.econjournals.com

2. Ahmed, S. (2005). Inflation and Economic Growth in Bangladesh : 1981-2005 Policy Analysis Unit * ( PAU ) Working Paper Series : WP 0604 Inflation and Economic Growth in Bangladesh : 1981-2005, (December).

3. Ahmed, S., \& Mortaza, M. (2010). Inflation and economic growth in Bangladesh: 1981-2005. Retrieved from https://ideas.repec.org/p/ess/wpaper/id3033.html

4. AYDIN, C. 2017. The inflation-growth nexus: A dynamic panel threshold analysis for D-8 countries. Romanian Journal of Economic Forecasting, 20, 134-151.

5. Ayyoub, M., Chaudhry, I. S., \& Farooq, F. (2011). Does Inflation Affect Economic Growth? The case of Pakistan. Pakistan Journal of Social Sciences (PJSS), 31 (1), 51-64. Retrieved from http://www.bzu.edu.pk/PJSS/Vol31No12011/Final_PJSS-31-1-05.pdf 
6. Barcola, M. \& Kebalo, L. (2018). Inflation-growth nexus and regional integration in West Africa. Journal of Economics and Development Studies, 6, 54-66. https://doi. org/10.2139/ssrn.3280476

7. Chimobi, O. P. (2010). Inflation and Economic Growth in Nigeria, 3(2), 159-166. https://doi.org/10.3386/w5326

8. Dickey, D., association, W. F. the A. statistical, \& 1979, undefined. (n.d.). Distribution of the estimators for autoregressive time series with a unit root. Taylor $\mathcal{E}$ Francis. Retrieved from https://www.tandfonline.com/doi/abs/10.1080/01621459.1979.1048 2531

9. Dufrénot, G., \& Mignon, V. (2002). Recent Developments in Nonlinear Cointegration with Applications to Macroeconomics and Finance. Boston, MA: Springer US. https:// doi.org/10.1007/978-1-4757-3615-1

10. Econometrics, M. O.-S. in E. and, (2007), undefined. (n.d.). A modelling of Ghana's inflation experience: 1960-2003. Ingentaconnect.Com. Retrieved from https://www. ingentaconnect.com/content/sabinet/bersee/2007/00000031/00000001/art00006

11. Enders, W. (2008). Applied econometric time series. Retrieved from https://scholar. google.ca/scholar?hl=en\&as_sdt $=0,5 \& q=$ Enders, + Walter. + Applied + Econometri c + Time + Series. + Hoboken: + Wiley, $+2015 .+$ Print.\&btnG\&pli=1

12. Feldstein, M. (1980). Inflation, tax rules, and investment: Some econometric evidence. https://doi.org/10.3386/w0577

13. Fischer, S., Economics, F. M.-R. of W., \& (1978), undefined. (n.d.). Towards an understanding of the real effects and costs of inflation. Springer. Retrieved from https:// link.springer.com/article/10.1007/BF02696381

14. Fountas, S. (2001). The relationship between inflation and inflation uncertainty in the UK: 1885-1998. Economics Letters, 74(1), 77-83. https://doi.org/10.1016/ S0165-1765(01)00522-5

15. Gregorio, J. (1999). Inflation, growth, and central banks: theory and evidence. Retrieved from https://elibrary.worldbank.org/doi/abs/10.1596/1813-9450-1575

16. Gujarati, D. N. (2009). Basic econometrics. Tata McGraw-Hill Education.

17. Ibrahim, M. H. (2015). Oil and food prices in Malaysia: a nonlinear ARDL analysis. Agricultural and Food Economics, 3(1). https://doi.org/10.1186/s40100-014-0020-3

18. Khan, M., papers, A. S.-I. S., \& 2001, undefined. (n.d.). Threshold effects in the relationship between inflation and growth. Springer. Retrieved from https://ink.springer. com/article/10.2307/4621658

19. MacKinnon, J. (1991). Critical Values for Co-integration Tests. \&quot; In RF Engle and CWJ Granger (Eds.), Long-Run Economic Relationships. Oxford: Oxford Univ. Press.

20. Madurapperuma, W. (2016). Impact of inflation on economic growth in Sri Lanka. Journal of World Economic Research, 5, 1-7. https://doi.org/10.11648/j. jwer.20160501.11 
Revisiting inflation and growth nexus in Bangladesh: an asymmetric cointegration based on non-linear ARDL approach

21. Mahmud. (1997). Growth or Stagnation? - A Review of Bangladesh's Development 1996 | The University Press Limited (p. 513). Dhaka,Bangladesh: Centre For Policy Dialogue (CPD). https://doi.org/978 9840513888

22. Mallik, G., Chowdhury, A., \& Wai, T. (2001). Inflation And Economic Growth: Evidence From Four South Asian Countries, Asia-Pacific Development Journal 8(1), $123-135$.

23. Mallik, G., Journal, A. C.-A.-P. D., \& 2001, U. (n.d.). Inflation and economic growth: evidence from four south Asian countries. Academia.Edu. Retrieved from http:// www.academia.edu/download/44781745/Inflation_and_economic_growth_evidence_f20160415-28548-oejbvn.pdf

24. Mamo, F. T. (2012). Economic Growth and Inflation A panel data analysis. Economics, $1-44$.

25. Mubarik, Y., \& Riazuddin, R. (2005). Inflation and growth: An estimate of the threshold level of inflation in Pakistan. Retrieved from http://www.sbp.org.pk/research/bulletin/2005/Article-3.pdf

26. Mundell, R. A. (1965). Growth, Stability, and Inflationary Finance. Journal of Political Economy, 73(2), 97-109. https://doi.org/10.1086/258999

27. Munir, Q., Mansur, K., \& Furuoka, F. (2009). Inflation and Economic Growth in Malaysia - A Threshold Regression Approach. ASEAN Economic Bulletin, 26(2), 180. https://doi.org/10.1355/ae26-2d

28. Omay, T., Van Eyden, R. \& Gupta, R. (2018). Inflation-growth nexus: evidence from a pooled CCE multiple-regime panel smooth transition model. Empirical Economics, 54, 913-944.

29. Paul, S., Kearney, C., Economics, K. C.-A., \& (1997), undefined. (n.d.). Inflation and economic growth: a multi-country empirical analysis. Taylor $\mathcal{E}$ Francis. Retrieved from https://www.tandfonline.com/doi/abs/10.1080/00036849700000029

30. Pesaran, M. H., Shin, Y., \& Smith, R. J. (2001). Bounds testing approaches to the analysis of level relationships. Journal of Applied Econometrics, 16(3), 289-326. https:// doi.org/10.1002/jae.616

31. Phillips, P., Biometrika, P. P.-, \& (1988), undefined. (n.d.). Testing for a unit root in time series regression. Academic.Oup.Com. Retrieved from https://academic.oup.com/ biomet/article-abstract/75/2/335/292919

32. Research, M. M.-J. of W. E., \& (2016), U. (n.d.). Impact of inflation on economic growth in Sri Lanka. Researchgate.Net. Retrieved from https://www.researchgate.net/ profile/Wasanthi_Madurapperuma/publication/304771434_Impact_of_Inflation_on_ Economic_Growth_in_Sri_Lanka/links/577a09d108ae1b18a7e6275a.pdf

33. Sarel, M. (1996). Nonlinear Effects of Inflation on Economic Growth. Staff Papers International Monetary Fund, 43(1), 199. https://doi.org/10.2307/3867357

34. Shin, Y., Yu, B., \& Greenwood-Nimmo, M. (2014). Modelling Asymmetric Cointegration and Dynamic Multipliers in a Nonlinear ARDL Framework. Festschrift in Honor of Peter Schmidt, 281-314. https://doi.org/10.1007/978-1-4899-8008-3_9 
Mohammed Akter Hossain • Hakan Acet • Zobayer Ahmed • Alauddin Majumder

35. Society, J. T.-E. J. of the E., \& (1965), Money and economic growth. JSTOR. Retrieved from https://www.jstor.org/stable/1910352

36. Sweidan, O. D. (2004). Does inflation harm economic growth in Jordan? An econometric analysis for the period 1970-2000. International Journal of Applied Econometrics and Quantitative Studies, 1(February 2004), 41-66. https://doi.org/10.1109/ MSPEC.2004.1265112 